\title{
Facilitating Students' Multiple Intelligences through RME: A Learning Trajectory of Volume and Surface Area Measurement
}

\author{
Ahmad Wachidul Kohar ${ }^{1 *}$, Achmad Dhany Fachrudin' ${ }^{2}$, Soffil Widadah ${ }^{3}$ \\ ${ }^{1}$ Pendidikan Matematika, Universitas Negeri Surabaya \\ ${ }^{2,3}$ Pendidikan Matematika, STKIP PGRI Sidoarjo \\ *ahmadkohar@unesa.ac.id
}

\begin{abstract}
Abstrak
Penelitian ini bertujuan untuk mendeskripsikan lintasan belajar pengukuran volume dan luas permukaan balok dan kubus dengan melibatkan kecerdasan majemuk dalam kegiatan pembelajaran matematika realistic (RME). Sebanyak 39 siswa kelas lima di sebuah sekolah dasar di Sidoarjo, Indonesia terlibat dalam tahap teaching experiment. Melalui dokumentasi, wawancara, dan observasi kelas, lintasan belajar hipotetik (HLT) yang dikembangkan dalam pilot experiment kemudian dianalisis dan direvisi untuk mendapatkan lintasan belajar yang dilaporkan dalam artikel ini. Lintasan belajar tersebut mencakup kegiatan menggulung kubus untuk menentukan jaring-jaring kubus/balok, membandingkan luas permukaan dan volume dua model dengan ukuran berbeda, mencari luas permukaan dengan jaring-jaring yang dibangun, membuat miniatur bangunan dengan model kubus satuan, memprediksi banyak kubus satuan dalam sebuah model kotak, menyusun berbagai model kubus dengan berbagai ukuran menggunakan jumlah kubus satuan tertentu, menyusun kembali sejumlah kubus satuan dengan ukuran yang berbeda untuk mendapatkan volume dan luas permukaan yang berbeda, dan membandingkan volume dua buah prisma segi empat yang dibuat dari model kertas berbentuk persegi panjang dengan ukuran yang sama. Terakhir, pada 'level formal' siswa mengembangkan pengetahuan informal mereka ke dalam konsep formal volume dan luas permukaan prisma, yang dalam hal ini adalah kubus dan balok.
\end{abstract}

Kata kunci: Lintasan Belajar, Kecerdasan Majemuk, Volume, Luas Permukaan.

\begin{abstract}
This is a design research which aims to describe the learning trajectory of volume and surface area measurement of rectangular prism by considering the involvement of the students' multiple intelligences within a set of realistic mathematics education (RME) learning activities. A total of 39 students of grade five at an elementary school in Sidoarjo, Indonesia were involved in teaching experiment stage. By collecting data through documentation, interviews, and classroom observations, the Hypothetical Learning Trajectory which was developed in pilot experiment was then revised to get a revised learning trajectory reported in this paper. Such a revised learning trajectory are the learning activities around drawing the nets of cube and cuboids through rolling activity, comparing surface are and volume of two models with different sizes, finding surface area using the constructed nets, building miniature buildings using cube unit model, predicting the number of unit cubes in a box, constructing various models of cuboids to various sizes using particular number of unit cubes, rearranging a number of unit cubes arrangements with different layers to get different volume and surface area, and comparing the volumes of two rectangular prism made from the same rectangular model of paper. Lastly, at the 'formal level' students developed their informal knowledge into formal concepts of volume and surface area of rectangular prism, which in this case is cuboid and cube.
\end{abstract}

Keywords: Learning Trajectory, Multiple Intelligences, Volume, Surface Area.

Received: Desember 26, 2020 / Accepted: January 28, 2021/ Published Online: January 28, 2021 


\section{INTRODUCTION}

Gardner (1999)'s theory of multiple intelligences has shown many benefits in the field of learning design, including mathematics learning. These benefits include being able to facilitate students with various types of intelligence (Armstrong, 2009; Kohar \& Rosyidi, 2013), promoting learners to explore and learn in a variety of ways so that their conceptualization and relational understanding of mathematics is strengthened (Gouws \& Dicker, 2011) , reducing the tendency of teachers to teach with methods that only correspond to the most prominent types of intelligence they have (Sulaiman, Abdurrahman, \& Rahim, 2010), improving mathematics learning outcomes (Işsı \& Tarım, 2009; Temur, 2007), and fostering students' motivation to learn mathematics (Bednar at al, 2002). These positive results are also supported by the view that each student may use a different set of types of intelligence to learn mathematical concepts and skills, not just logical-mathematical intelligence (Adams, 2000). This quote indicates that each student may learn mathematics using different variations of intelligence even though mathematics is built on the basis of logical, critical and deductive thinking which involves more logical-mathematical intelligence.

In fact, many instructions do not facilitate to the diversity of students' intelligences. In addition, many mathematics learning curricula nowadays cover too many learning topics which do not facilitate this diversity of intelligences, creating serious difficulties in student success (Tezer, Ozturk, \& Ozturk, 2015). Whereas according to Gardner (1999), the most important thing in learning practice is that teachers are able to recognize and maintain the diversity of students' intelligence because they have different combinations of intelligences. To bring multiple intelligences in mathematics learning, learning is needed in accordance with the theory of multiple intelligences (Armstrong, 2009; Karamikabir, 2012). Armstrong (2009: 64) argues that the best way to approach a curriculum that uses multiple intelligences theory is to think about how a teacher can translate the material taught from one type of intelligence to another. Thus, implementing mathematics learning with the theory of multiple intelligence can be designed by thinking about how a mathematical concept or skill being taught is translated from mathematical structures which are the symbols of logical-mathematical intelligence into other symbols of intelligences such as language, figures, musical and physical expressions, social interaction, self-reflection, and nature. Therefore, Armstrong (2009: 65-67) recommends that learning be designed by considering the possibility of an intelligent approach that fits the selected mathematics topic, selecting and ordering activities in the learning plan, and then applying it to the learning process. 
Studies on the development of multiple intelligence-based learning designs have indeed been carried out with various research focuses. For examples, Hasmiwati and Widjajanti (2020) implemented the theory of multiple intelligences combined with scientific approach to improve students' mathematical literacy, while Hasnidar et al (2020) develop students' multiple Intelligences using Two Stay Two Strays Type learning approach with aiming at improving students' social interaction. However, research which specifically discuss how the multiple intelligence theory is applied in a typical mathematics learning which considers learning trajectory is rarely reported. In fact, currently many mathematics learning designs are developed based on a unique learning trajectory through design research activities using a realistic mathematics approach (Gravemeijer \& Cobb, 2006). This research design was carried out with the aim of producing a local instructional theory (LIT). LIT itself is a theory that describes assumptions about learning trajectories on a particular topic, a series of learning activities and the methods used to support this learning (Gravemeijer, 2004). It is said to be a local theory because the theory only discusses specific topics (domain-specific), namely specific topics in mathematics. Thus, in relation to the theory of multiple intelligences, LIT can be viewed as a realistic mathematics education theory that supports the involvement of students' multiple intelligences as a reference in design research (Gravemeijer, 2004).

Many of the LITs developed using a realistic mathematical approach are indicated to be able to support the involvement of students' multiple intelligences. In Indonesia, these results, for example, can be seen from the research of Bustang et al. (2013), Fatoni et al. (2015), Salmah $\&$ Putri (2015), and Wijaya (2008). Through the context of traditional games used by Fatoni and Wijaya, for example, students are actively involved in playing activities (kinesthetic intelligence), discussing the results of group collaboration (verbal, interpersonal intelligence), representing the results of group work in the form of images (visual / spatial intelligence), doing mathematical reasoning activities to solve the problems posed (logical-mathematical intelligence), and reflecting on the games that have been done (intrapersonal intelligence). In theory, the characteristics of a realistic mathematics approach also support the involvement of students' multiple intelligences in learning. The use of context characteristics, for example, can be applied by paying attention to the use of examples of problems related to the surrounding environment or living things to support the involvement of naturalistic intelligence, while the characteristics of interactivity are applied to support the involvement of students' interpersonal and intrapersonal intelligence. Considering this potential, researchers argue that it is possible to develop a realistic mathematics learning design that covers as many as types of multiple intelligences. In this regard, Murni and Ruqoyyah (2020) has actually integrated multiple 
intelligences into their teaching material which use RME approach. However, it was not explicitly designed to use any learning trajectory within such a teaching material. In this research, the teaching materials were designed based on the learning trajectory developed to facilitate students' multiple intelligences.

One of the specific topics in mathematics learning at the elementary school level that has been widely developed is the measurement of surface area and volume of rectangular prisms (cubes and cuboids), such as through spatial visualization activities (Revina \& van Gallen, 2011; Sack, 2013), measurement process using repeated informal units (Curry et al, 2006), and the relationship between surface area and volume of space (Taylor \& Jones, 2013). At the elementary school level, the concept of understanding volume needs to be instilled in students before they carry out investigations into finding ways to find the volume of the building itself. This concept can be imparted by giving experience how to compare two objects by asking which one is greater. Learning can begin with a discussion such as with a question: which one usually requires more water to its fullest, bath or toilet tub. Through interactive discussions, students will come up with answer ideas according to the experiences they have gained, such as by estimating more water content in terms of the shape and size of each type of tub or estimating how many times they moved water from the well to the two types of tubs. These all activities are in line with the idea of Van den Heuvel-Panhuizen (2008) who reveals that in teaching volume, students need to be given experience comparing the contents of objects that are useful to achieve an understanding of the concept of volume. After students understand the concept of building volume, learning can continue by investigating how to find the volume of a solid. Media such as unit cubes can be used as the smallest unit to form a shape such as cuboids / cubes. By identifying the relationship of length, width, and height of the cuboid / cube with the number of unit cubes needed to fulfill a cuboid / cube model, it is hoped that students can find the formula for the volume of cuboids and cubes by themselves.

With a realistic mathematical approach, the daily problems that have been stated above can be a context for starting to involve students in activities to find the concept of the volume of a space to finding the formula for the volume of a shape. The role of these problems as context in this case as expressed by Treffers and Goffree (in Wijaya, 2012: 33) that context acts as a tool to form concepts, which in this case the concept of understanding the volume of space, and context as tools for developing models (model forming), which in this case are strategies for rediscovering formulas or strategies to find volume of any shapes. Henceforth, these activities can be designed with attention to the types of multiple intelligences as described by Gardner. 
Therefore, the research question addressed in this study is "How is the learning trajectory that can involve students' multiple intelligences in learning volume and surface area measurements?"

\section{METHOD}

This is a design research consisting of three stages, namely 1) the design and preparation phase (thought experiment), (2) the teaching experiment phase (instruction experiment), and (3) the retrospective analysis (Gravemeijer \& Cobb, 2006; 2009). While the pilot experiment was reported in the previous paper (see Susilo et al, 2018), this paper mainly discusses the report of the research in stage II carried out in a class of 39 fifth grade students from an elementary school in Sidoarjo, East Java, Indonesia.

\section{Stage I: Preliminary design}

The main objective at this stage is to formulate a hypothetical learning trajectory (HLT) that is elaborated and improved upon during the experiment. HLT is dynamic in nature and can be adjusted to the thinking strategies of students that occur during the experimental design. Therefore, the first step that must be taken at this stage is to review the literature measuring volume and surface area of cuboids and cubes, the RME approach, the 2013 curriculum and design research methods as a basis for designing learning trajectories. In detail, the things that are done in this stage are (1) analyzing the learning objectives, (2) determining and establishing the initial conditions for the research, (3) designing and discussing the conjecture or HLT to be developed, (4) determining which intelligences of Gardner's theory that can be facilitated in each of instructional tasks, and (5) determining the class character and role teacher.

\section{Stage II: Teaching experiment}

The activities carried out in this second stage were implementing the learning designs that have been designed in the first stage. There were two cycles at this stage, namely the pilot experiment as cycle 1 and the teaching experiment as cycle 2. The pilot experiment, whose results was reported in our previous work (Susilo et al, 2018), was carried out to try out the HLT. There were only six students involved in the pilot experiment, whose class was different from the class involved in the teaching experiment. The six students were selected by the teacher so that they could represent high, medium, and low ability students. In this case, the researcher acts as a teacher. This stage aims to improve the quality of the HLT that has been designed so that a better HLT is obtained to be applied in cycle 2 . 


\section{Stage III: Retrospective analysis}

The purpose of this stage is to develop a local instructional theory. At this stage, all data obtained during the teaching experiment were analyzed and the results were used to plan activities or to develop designs for subsequent learning activities. HLT serves as the main reference for determining what things are the focus of doing the analysis. HLT was then compared with actual learning, in this case the students' thinking strategies and processes that actually occur during learning. The things analyzed were not only things that supported HLT but also examples which contradicted the conjecture that was designed.

In summary, the research framework is describe in Figure 1.

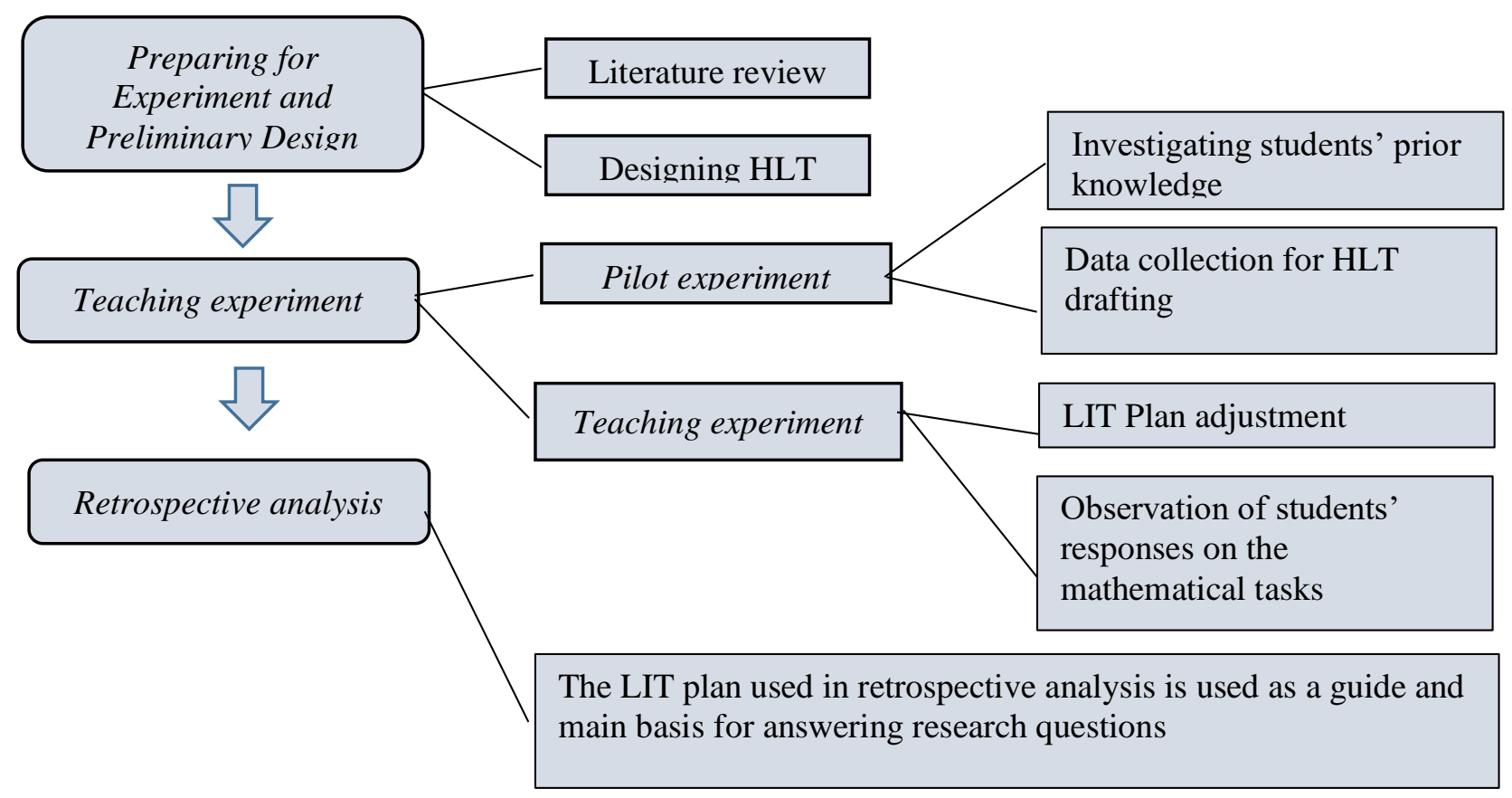

Figure 1. Research Framework

\section{Validity and Reliability of Research Results}

Validity is carried out with a focus on examining the quality of the data collected and generated. To increase internal validity, during retrospective analysis, HLT was compared with various data from different sources such as video recordings, photos, student work, interviews and field notes. Thus, HLT is a means to support validity, namely as a new and reference point in answering research questions. This is to connect and initial guesses so that existing data can be prevented from systematic bias. Meanwhile, reliability shows the consistency of the results of the research. Reliability in this study is internal and external reliability. Internal reliability refers to reliability in research projects (Bakker, 2004). In this study, internal reliability was carried out by discussing important segments at the time of conducting teaching experiments 
with researchers, peers, and model teachers. This interpretation is to prevent the subjectivity of researchers in interpreting the data and triangulating the data, namely field notes, observation sheets, interviews, and video recordings of the actual learning that guides the implementation of instructional activities.

\section{RESULTS}

This research produces a learning trajectory for learning volumes and surfaces of cuboid and cube facilitating students' multiple intelligences. Furthermore, the results and discussion of these stages are described as follows.

\section{Preliminary Design}

In the first stage, the researcher developed a hypothetical learning trajectory (HLT). The HLT preparation activity was preceded by an analysis of the curriculum which aims to make learning designed in accordance with the mathematics curriculum applicable to grade five as the subject in learning activities. The analysis includes the determination of teaching materials, learning objectives, and learning indicators. After determining the learning objectives and indicators, the next activity was to analyze the results of the students' pretest regarding the material surface area of cuboids and cubes and their volume. In this pretest, students were given a set of questions regarding the cube network, the volume of the cube, and its surface area which are presented in the form of a contextual problem. The pretest was given to six students as the subjects of the small group. Results of the pretest indicates that the students' spatial ability, which is an indicator of visual / spatial intelligence, has not looked well, as evidenced by the wrong answers to questions related to cube nets. These results indicate the need for activity designs that can train students to develop visual/spatial intelligence, which is an important intelligence to be involved in solving the problem of volume and surface area of spaces. Other findings indicate that students only performed baseless rules of multiplication and addition operation on a volume-related task without supporting contextual considerations. It indicates a need for activity designs that support students to involve their visual / spatial intelligence to determine the relationship between length, width and height of a cuboid / cube. in order to find the volume.

Our classroom observation notes in partner teacher classes, students have begun to appear active in learning activities, both during questions and answers with the teacher, and during group discussions. This shows that student's interactivity as one of the characteristics of RME began to emerge. Therefore, in this study, interactivity will be raised again in learning 
activities, namely during the initial activity when the teacher questions and answers material as a learning stimulus, core activities when students work in groups and presentations of group work, and the final activity when the teacher and students conclude the lesson. This series of activities aims so that students can construct their own understanding of the problems given so that it is useful to move to the next mathematical process (student's contribution). Another characteristic, the intertwining of learning strands, is expected to appear when students investigate how to find the volume of cuboids and cubes. This knowledge can be in the form of multiplication skills and the concept of rectangles / squares and how to find their area.

In connection with how multiple intelligences are performed by students, a schematic diagram is shown in Figure 2.

\section{kinesthetic intelligence:}

how to include gestures in understanding the volume of a cube?

interpersonal intelligence:
how to activate students when
working in groups and in
discussion?
linguistic intelligence:
how to use the language
appropriate to the topic? How
do students communicate
problem solving ideas?
visual / spatial intelligence:
how to use visual aids, color, art, and
metaphors in this topic?

musical intelligence:

how to bring music such as songs and instruments into this topic?

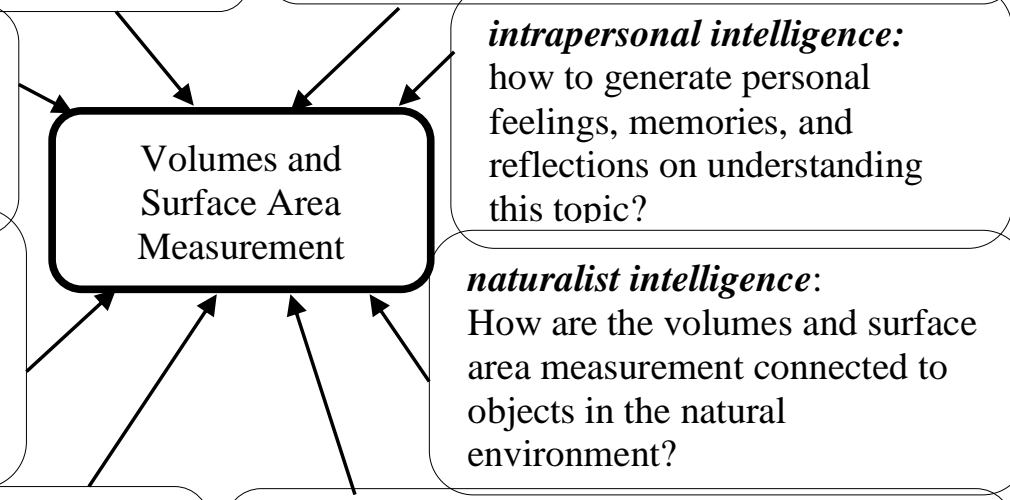

logical-mathematical intelligence:

How can computational, logic, and critical thinking skills be incorporated into this topic?

Figure 2. Framework of how multiple intelligences performed within learning activities

Figure 2 illustrates how mathematics learning involving students' multiple intelligences are organized by the answers of the questions in each box. The answer, which represents how the learning design will facilitate each type of student intelligence, shows the diversity of students' characters in responding to learning that teachers may encounter in class. In relation to the learning trajectory developed in this study, this diversity will be facilitated by almost every activity even though some types of intelligence cannot be facilitated explicitly due to the character of the activity. For example, for those who have dominant visual/spatial intelligence, they will be very helpful when trying to draw nets of cube on their work paper. Likewise, those who have a dominant kinesthetic intelligence, they will be helped when carrying out bodily 
activities in determining the cube nets using a cube model. For those who have dominant verbal intelligence, they will be helped when expressing ideas verbally or in writing to find and compare cube nets. Once the answers from each box are obtained, then each activity that has been studied based on a HLT that takes into account the principles and characteristics of RME is rearranged by taking into account the involvement of multiple intelligences in accordance with these answers. The initial HLT was prepared in our previous work (Susilo et al, 2018). Based on the retrospective analysis of such an initial HLT, the revised HLT for being used in the teaching experiment is presented in Table 1.

\section{$\underline{\text { Teaching experiment }}$}

The teaching experiment was carried out for eleven activities organized in four meetings. Activity 1 until activity 11 in Table 1 were used to collect data of students' responses on the activities as well as teaching observation.

\section{Activity 1: Guessing which package contains more clay and need more paper to wrap?}

In responding Figure 3, some students think that Figure 3a contains more clay, because it looks bigger than Figure $3 \mathrm{~b}$, while figure $3 \mathrm{~b}$ requires more wrapping paper because it looks longer. Thus, students have not comprehensively compared the measures of length, width, and height of each shape, so there is no mathematical logical answer that clarify their claims. In conclusion, in comparing the volume of rectangular prism, students basically have learned to use the concept of volume correctly when presented in a unit cube arrangement, while students find it difficult to compare the volume of a spatial shape that is not presented in the form of a unit cube arrangement.

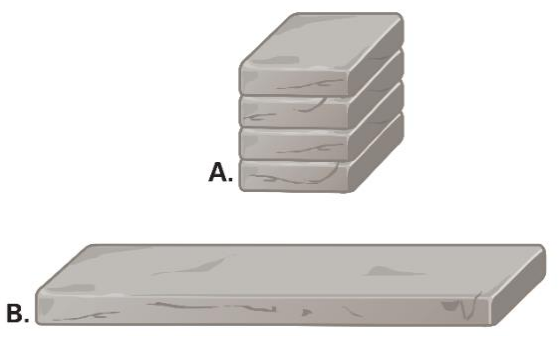

Figure 3a and 3b
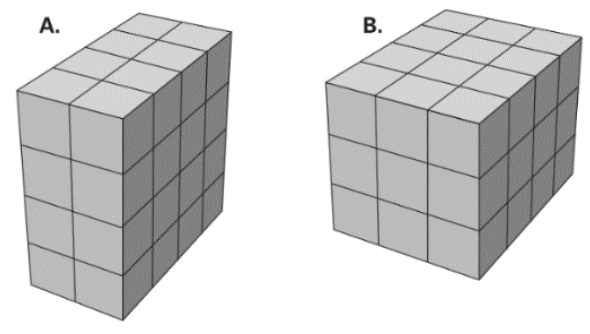

Figure of $4 a$ and $4 b$

Activity 2: discovering the volume concept through the activity 'which box is bigger?' As a model of, students carry out the activity of comparing the size of two shapes (paper cuboid model with a size of $3 \times 1 \times 3$ units and a cube model with a size of $2 \times 2 \times 2$ units) using rice and unit cubes. Several findings related to this comparison occurred. When comparing rice, several groups complained that the rice provided was not sufficient to fully fill the two items being compared. Another group fills the rice into the smaller object first (in this case the cube), so 
that when the rice is poured onto the bigger object (cuboid), the rice does not fill the object. At first the students were confused, so they added the load of rice to the bigger object. For the comparison activity using the unit cube, most of the students did correctly. They easily know that a cuboid needs nine unit cubes, while a cuboid needs 8 unit cubes, by plugging the unit cubes into each of the space cubes. This led them to the conclusion that a cuboid is bigger than a cube.

\section{Activity 3: Finding the nets of cubes and cuboids through rolling activity}

In this activity, students were invited to determine the nets of cuboids and cubes, find a number of possible numbers of cuboid nets and cubes, and draw cuboids and cube nets. To find cube nets, students are invited to do the activity of rolling a cube model that has been colored differently on each side, then making a rectangular trail from each side attached to the drawing paper. The purpose of coloring the different sides of the cube is so that students are able to recognize the side whose traces have been drawn on the paper so that no side trace is drawn more than once. This is also to facilitate those who use their visual/spatial intelligences in which colors might can help them understand the rule of tracing and identify the trace more easily. The same activity was also be done to find cuboid nets. Figure $4 \mathrm{a}, 4 \mathrm{~b}$, and $4 \mathrm{c}$ respectively show an example of net of the cube model, the sequence of traces of finding a cube net, and students' rolling activity.

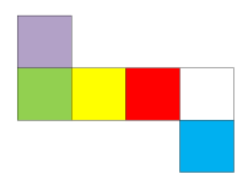

Figure 4a

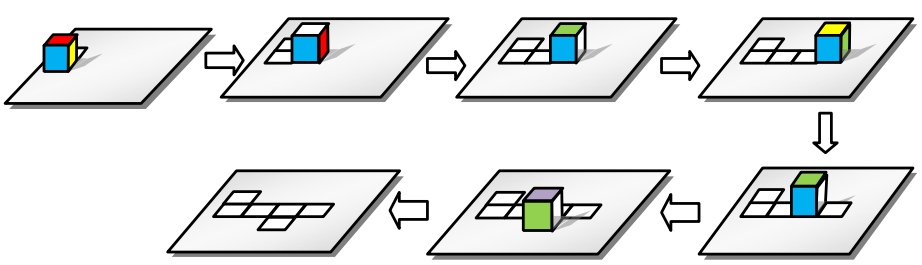

Figure 4b

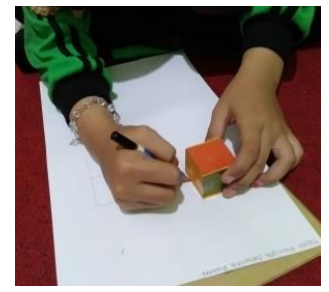

Figure 4c

Figure 4. Rolling activity 
Inovasi Matematika (Inomatika)

Vol. 3 No. 1, Januari 2021, hal.27 - 50
DOI: $10.35438 /$ inomatika.v3i1.248

https://inomatika.unmuhbabel.ac.id/inomatika

Table 1. The HLT of Volume and Surface Area of Cube/Cuboid

No Activity Goals

Students' conjectured thinking

\section{Volume and Surface Area}

1 Compare two models of cuboids Students can build an of different sizes in terms of more wrapping paper needed to wrap all surfaces and more clay loaded in the model. understanding of the concept of cuboid/cube volume and surface area
- Only consider cuboid that 'appear larger' or 'longer' are those that have a larger volume or surface area, without any logical reason

- Compare by cutting the longer model into some pieces then rearrrange the pieces like the other one, then guess which one is higher

2 Discover the volume concept through the activity 'which box is bigger?'

Students can find the strategy of comparing volume of two cuboid model with informal way

- Consider that a cuboid containing more sand or unit cubes is a cuboid with more volume.

Students can find as many as possible the arrangement of cube nets and cuboid nets through a rolling activity using cube model whose sides are different in colors

4. Use rectangular models of paper of various sizes to be used as models for the cube/cuboid nets, and then determined the total area which represent surface area of cuboid/cube.
- Students can use the understanding of square and rectangular areas to determine the area of cube/cuboid nets

- Students can construct the formula of the surface area of cubes and cuboids
- Find all eleven cube nets with pattern of 1-4-1, 2-3-1, 2-2-2, and 3-3.

- Consider a net of cube and its rotation are two distinct patterns

- Consider that each of the two opposite sides of the cuboid had the same shape and area so that three pairs of rectangular models of paper were needed to form the cuboid net.

- Attaching the rectangular paper model carelessly without paying attention to the appropriate size so as to form a net of cuboid

\section{Dominantly Activated} Intelligences

Logical-mathematical, verbal/linguistic, visual/spatial, interpersonal, intrapersonal

Logical-mathematical, verbal/linguistic,

visual/spatial, interpersonal, intrapersonal Logical-mathematical, verbal/linguistic,

kinesthetic,

visual/spatial, interpersonal, intrapersonal

\section{Logical-mathematical,} verbal/linguistic,

visual/spatial,

kinesthetic 


\begin{tabular}{|c|c|c|c|c|}
\hline No & Activity & Goals & Students' conjectured thinking & $\begin{array}{l}\text { Dominantly Activated } \\
\text { Intelligences }\end{array}$ \\
\hline 5 & $\begin{array}{l}\text { Draw a 'milo cube' arrangement } \\
\text { resembling a cuboid located on a } \\
\text { table and build miniature } \\
\text { buildings using 'milo cube' } \\
\text { model }\end{array}$ & $\begin{array}{l}\text { - Students can present a three- } \\
\text { dimensional arrangement of } \\
\text { objects into two-dimensional } \\
\text { images based on different } \\
\text { viewing positions (top view, } \\
\text { side view, and front view) and } \\
\text { understand the interior of the } \\
\text { cube/cuboid } \\
\text { - Students can arrange cuboids } \\
\text { consisting of unit cubes based } \\
\text { on different view images (top } \\
\text { view, side view, and front view) }\end{array}$ & $\begin{array}{l}\text { - Consider that different viewing cause } \\
\text { different image results } \\
\text { - Consider only one or two view as the } \\
\text { basis for predicting the number of unit } \\
\text { cubes } \\
\text { - Performed double-counting on the } \\
\text { model sides }\end{array}$ & $\begin{array}{l}\text { Visual/spatial, } \\
\text { interpersonal, } \\
\text { kinesthetic }\end{array}$ \\
\hline 6 & $\begin{array}{l}\text { Find the number of 'rice boxes' } \\
\text { in an image showing the } \\
\text { construction of a cuboid-shaped } \\
\text { space }\end{array}$ & $\begin{array}{l}\text { Students can calculate the number } \\
\text { of unit cubes (model of rice boxes } \\
\text { in the figure) based on the view } \\
\text { from above, side, and front based } \\
\text { on previous activity experience } \\
\text { by paying attention to the number } \\
\text { of unit cubes found in each layer }\end{array}$ & $\begin{array}{l}\text { Consider the number of layers } \\
\text { represent the height if the rectangular } \\
\text { prism model and the number of rice } \\
\text { boxes of each layer represent the area } \\
\text { of rectangle } \\
\text { - Unable to accurately enumerate rice } \\
\text { boxes within the image structure if any } \\
\text { of the rice boxes were hidden }\end{array}$ & $\begin{array}{l}\text { Visual/spatial, } \\
\text { interpersonal, } \\
\text { kinesthetic }\end{array}$ \\
\hline 7 & $\begin{array}{l}\text { Construct various models of } \\
\text { cuboids to various sizes using } 36 \\
\text { models of 'milo cube' }\end{array}$ & $\begin{array}{l}\text { Students can build strategies of } \\
\text { finding measure of cuboid with a } \\
\text { given volume }\end{array}$ & $\begin{array}{l}\text { - Construct a model of cuboid by } \\
\text { considering three factors of } 36 \text { as } \\
\text { numbers representing the length, } \\
\text { width, and height of cuboid. } \\
\text { - Repeatedly misarrange the unit cubes } \\
\text { to form a cuboid of volume } 36 \text { without } \\
\text { noticing that } 36 \text { is the product of three } \\
\text { positive integers representing the } \\
\text { length, width, and height of the } \\
\text { cuboid. }\end{array}$ & $\begin{array}{l}\text { Logical-mathematical, } \\
\text { visual/spatial, } \\
\text { interpersonal, } \\
\text { intrapersonal, } \\
\text { kinesthetic }\end{array}$ \\
\hline 8 & $\begin{array}{l}\text { Finding the number of milo } \\
\text { cubes needed to to fill a box with } \\
\text { a known size }\end{array}$ & $\begin{array}{l}\text { Students are able to estimate the } \\
\text { volume of rice boxes that can be } \\
\text { loaded by a box by paying }\end{array}$ & $\begin{array}{l}\text { - Consider the number of milo cubes } \\
\text { needed is the difference between the } \\
\text { volume of the box (represented by the }\end{array}$ & $\begin{array}{l}\text { Logical-mathematical, } \\
\text { visual/spatial, }\end{array}$ \\
\hline
\end{tabular}




\begin{tabular}{|c|c|c|c|c|}
\hline No & Activity & Goals & Students' conjectured thinking & $\begin{array}{l}\text { Dominantly Activated } \\
\text { Intelligences }\end{array}$ \\
\hline & & $\begin{array}{l}\text { attention to the size of the length, } \\
\text { width, and height of the box }\end{array}$ & $\begin{array}{l}\text { number of milo cubes filling the box } \\
\text { when full) and the number of milo } \\
\text { cubes existing in the box. }\end{array}$ & $\begin{array}{l}\text { interpersonal, } \\
\text { kinesthetic }\end{array}$ \\
\hline & $\begin{array}{l}\text { Surface Area and Volume } \\
\text { Relationships }\end{array}$ & & & \\
\hline 9 & $\begin{array}{l}\text { Rearranging a number of milo } \\
\text { cube arrangements with different } \\
\text { layers }\end{array}$ & $\begin{array}{l}\text { Students can determine different } \\
\text { surface areas for the volume of } \\
\text { the same shape, then determine } \\
\text { which area is the smallest / } \\
\text { largest }\end{array}$ & $\begin{array}{l}\text { - Consider that two cuboids with the } \\
\text { same volume can have different } \\
\text { surface area } \\
\text { Consider that surface areas of two } \\
\text { cuboids with the same volume are also } \\
\text { the same. }\end{array}$ & $\begin{array}{l}\text { Logical-mathematical, } \\
\text { visual/spatial, } \\
\text { interpersonal, } \\
\text { intrapersonal, } \\
\text { verbal/linguistic }\end{array}$ \\
\hline 10 & $\begin{array}{l}\text { Comparing the amount of sand } \\
\text { needed by two different } \\
\text { rectangular prism models formed } \\
\text { by paper of the same size. }\end{array}$ & $\begin{array}{l}\text { Given two pieces of paper of the } \\
\text { same size }(e . g . p \times l) \text {, the } \\
\text { students gives justification which } \\
\text { will give a greater volume: } \\
\text { rectangular prims formed by } \\
\text { pasting the sides with the length } \\
\text { of } p \text { or rectangular prims formed } \\
\text { by pasting the sides with the } \\
\text { length } l) \text {. }\end{array}$ & $\begin{array}{l}\text { - Consider that two different } \\
\text { rectangular prism have the same } \\
\text { surface area could have different } \\
\text { volumes. } \\
\text { - Consider that the rectangular prism } \\
\text { formed by pasting the sides with the } \\
\text { the length of } p \text { has the greater volume } \\
\text { since it looks 'higher'. } \\
\text { - Consider that the rectangular prism } \\
\text { formed by pasting the sides with the } \\
\text { the length of } l \text { has the greater volume } \\
\text { since it looks 'fatter'. }\end{array}$ & $\begin{array}{l}\text { Logical-mathematical, } \\
\text { visual/spatial, } \\
\text { interpersonal, } \\
\text { intrapersonal, } \\
\text { verbal/linguistic }\end{array}$ \\
\hline 11 & $\begin{array}{l}\text { Sing a song related to the } \\
\text { volume of cuboids and cubes to } \\
\text { strengthen students' retention of } \\
\text { the volume and surface area } \\
\text { mesurement. }\end{array}$ & $\begin{array}{l}\text { Strengthen the understanding of } \\
\text { terms and formulas related to } \\
\text { rectangular prisms }\end{array}$ & - & Musical, interpersonal \\
\hline
\end{tabular}


Inovasi Matematika (Inomatika)

Vol. 3 No. 1, Januari 2021, hal.27-50
DOI: 10.35438/inomatika.v3i1.248

https://inomatika.unmuhbabel.ac.id/inomatika

In the rolling activity, bodily-kinesthetic and visual / spatial intelligence are more involved because they are related to the activity of rolling model of cube with hand movements and drawing activities of the findings of cube nets. Of all the cube net patterns found by the students, only the 1-4-1 pattern where it consists of a series of four square sides in a row in the middle which is then followed by 1 square on the left and right sides. Meanwhile, cube nets with patterns of 2-3-1, 2-2-2, and 3-3 did not appear in the students' responses.

\section{Activity 4: Find the surface area of cuboids and cubes based on their nets}

In this activity, students assemble various rectangular models of various sizes into the nets of cuboid or cube. The sizes of the square / rectangular models presented are $2 \times 2,2 \times 3,3 x$, $3,3 \times 3,3 \times 4,4 \times 4$, and $4 \times 5$. After assembling the nets, students are asked to determine the total area of the rectangular / square size model that has been selected. This activity challenges students to determine suitable combinations to make cuboid nets. On the first occasion, students tend to simply take existing models and draw closer to one another, without paying attention to the appropriate size. In addition, students also do not realize that they actually need to find a maximum of three pairs of rectangular sizes so that the nets are arranged incorrectly. These findings indicate that there is a need for more reinforcement for students regarding the variety of cube nets. Within this activity, students were guided to summarize the way they do to get to the formula for surface area of cuboid. The following excerpts and figure indicate how students find the surface area of the cuboid model.

From the excerpt for Figure 5, the students already know how to arrange the cuboid net with correct size. However, they did not yet come to the idea of simplifying the calculation to get the formula of surface area. They were not aware of the pairs of rectangle which have the same size so that it can be simplified using distribution law of integer operation, which is $2 \times 3 \times 4+2 \times 3 \times 3+2 \times 3 \times 4=2(3 \times 4+3 \times 3+3 \times 4)=2(12+9+12)$. Thus, this finding were then confirmed in the class discussion so that they came to the idea that the surface area can be calculated by the simplest formula, namely $2(p \times l+p \times t+l \times t)$. 


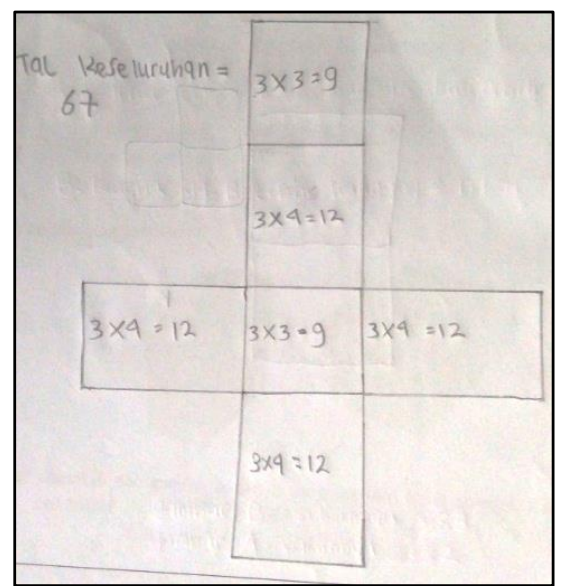

Figure 5. A cuboid net completed with sizes created by a group of students
Teacher:Tya and Nita, how did you arrange this net

Tya: We looked for the rectangles which have at least one side with the same length. For example, I found that these two sides $(3 \times 3$ and $3 \times 4)$ has a side with the same length, which is 3 .

Teacher:Then, how would you find the surface area of the cuboid?

Tya: We added up all the areas in this net, resulting $9+12+12+9+12+12=$ $48+18=66$

Teacher: Can you simplify your calculation?

Nita: I think this is simple already.

\section{Activity 5: Finding the number the cube units based on the front, back, and side views}

This activity aims to construct the volume concept of a cube by compiling a number of cube models and drawing the appearance of the arrangement from various directions, where the dominant multiple intelligences involved is visual intelligence. Some tasks were given as follows.

1. Take the twelve cubes. Then, make an arrangement of unit cubes according to your taste. Then draw the display shape from the front, top, and right side of the arrangement. Do you find another arrangement with the 12 cubes? If so, draw such an arrangement.

2. Arrange the unit cubes provided so that they form an arrangement with the front view, top view, and right side view as shown below. How many unit cubes do you need?

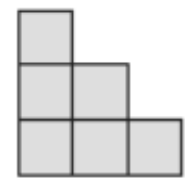

front

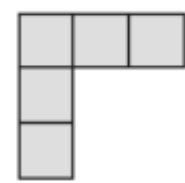

top

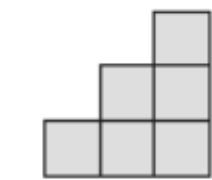

side view on the right

Figure 6. Problems of activity 3
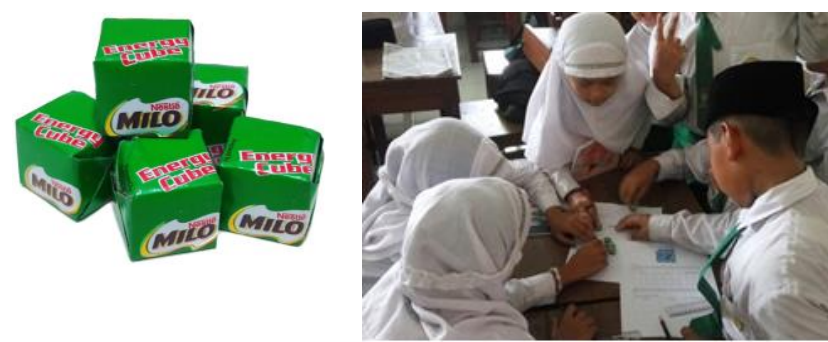

Figure 7. Students were discussing problem on activity 5 using some 'milo' cubes

Figure 7 shows a group discussion which tried finding the number of milo cubes by trial and errors. In this activity, they did some ubiquitous "double-counting" errors when determining 
the number of milo cubes within the structure given in the task. For instance, when a group in Figure 7 tried to enumerate the cubes needed to make the structure given in Figure 6 , they counted all cube faces that appeared on the six sides of the building, double-counting edge cubes and triple-counting corner cubes. Because they could not properly coordinate what he saw on the different sides of the building, they failed to realize when adjacent cube faces were part of the same cube. However, after the help of teacher to clarify their understanding, they tried several times to get the correct number of milo cubes, which is 9 milo cubes.

\section{Activity 6: Find a strategy to find the volume of cuboid through the 'rice box' problem.}

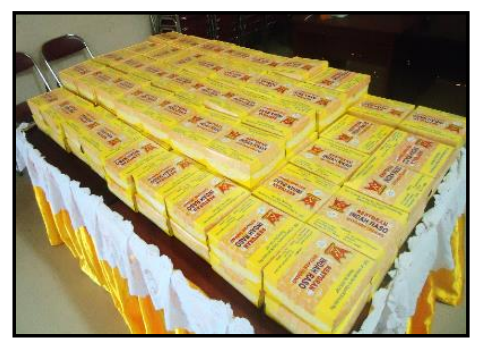

Figure 8. Rice box problem

In this activity, students investigated informal strategies for finding the number of rice boxes as shown in Figure 8. Some students enumerated the rice boxes and guessed the number of them, while others tried using the formula of rectangle for finding the number of rice boxes in each layer. However, some students considered that there were two layers which have the same measure which lead them multiplied the product of length and width by two, instead of finding the number of rice boxes one by one layer.

\section{Activity 7: Construct a cubic and cuboid arrangement model from a 'unit cube model' of various sizes, but with a fixed volume.}

When discussing the volume of cubes and cubes, students are invited to find the volume formula for cubes and cubes and use them in determining the volume of a cuboid / cube, solving problems related to cuboids and cubes and determining the change in volume of a cuboid / cube if the size of the sides is changed. In finding the formula for volume of cubes and cubes, students are given a number of unit cube models to be arranged into a number of cuboid and cube models, then determine the required number of unit cubes which represent the volume of each cuboid / cube model that has been made. This activity involves a lot of kinesthetic and visual / spatial intelligence because students need to move the unit cubes to form a cube / cuboid model, then draw a sketch of the model. The results of the work in this activity can be seen in the following figure. The finding in this activity was that students also tended to arrange the 36 unit cubes in 
moderation, without paying attention to the length, width, and height according to the number of satua cubes provided. After the discussion, the students rearranged the unit cubes into cuboids with sizes $36 \times 1 \times 1,4 \times 3 \times 3$ and $6 \times 3 \times 2$, while other sizes such as $9 \times 4 \times 1,9 \times 2 \times 2$, or $6 \times 6 \times 1$ were not found.

\section{Activity 8: Finding the number of milo cubes needed to fill a box with a known size.}

In this activity, the teacher gives each group a container that is sufficient to contain 120 milo cubes ( 6 milo x 5 milo x 4 milo). However, students were only given 12 milo cubes. With this number, students were asked to predict the number of milo cubes that were still needed so that the container was full. The results of the students' discussion showed several strategies, including 1) arranging horizontally, 2) arranging upwards, 3) compiling a combination up and horizontally. At first, students had difficulty finding the remaining total because of the limited milo cube provided by the teacher. There is a group of students who find a combination strategy to arrange it upwards and horizontally. Because the student already knows that there need to be 6 milos horizontally to the side, he needs to find a lot of milo horizontally to the back. Therefore, students move a number of milo cubes from horizontal to side to horizontal to back. The same way is done for the milo needed for the top arrangement.

With the strategy that the students had done in solving the rice box context problem, namely by counting per layer, the students completed this task to determine the volume of the container indicated by the maximum number of milo cubes that could be loaded. Interestingly, some students stated directly that to find the number of milo cubes needed is to multiply the number of milo cubes in the horizontal arrangement to the side, with the the number of milo cubes in the horizontal arrangement to the back, and then the result is multiplied by the number of milo cubes in the upward arrangement. Then, to find the required milo cube students, students subtracted the maximum total possible milo cube that can be loaded with the 12 milo cube available.

\section{Activity 9: Rearranging a number of milo cube arrangements with different layers}

Students were given a set of milo cubes (36 units) then they arrange them into other forms of cuboid with the same number of milo cubes. Afterwards, they calculate the surface area of each cuboid model. After finding all the surface areas they compare those to find the smallest surface area with the purpose of finding the size (length, width, and height) which makes the cuboid model has the smallest surface area because of the economical interest. Findings indicate that some students did not consider the factors of 36 as the representation of 
the cuboid size. Instead, they directly arranged by putting one by one milo cube to make a rectangular shape for the base (the most bottom layer) followed by the second layer with the same number of milo cubes. A mistake occurred when they failed to get enough milo cubes to complete the most top layer. For example, a group of students determine the size of $5 \times 3$ for both the base layer and the second layer. However, they got only the remaining six milo cubes for the most top layer, whereas to complete this layer, they actually need another nine milo cubes.

\section{Activity 10: Comparing the amount of sand needed by two rectangular prisms}

Students were challenged with the problem of determining which prism has a bigger volume so that it can load more sand. They were provided with a paper model measuring 12 $\mathrm{cm} \times 16 \mathrm{~cm}$. Then, they were asked, "If the prism that you are going to make is placed on a base, which one contains more sand: a rectangular prism formed by gluing the sides of paper $16 \mathrm{~cm}$ or $12 \mathrm{~cm}$ long?". As predicted, many of the students consider that two different rectangular prism which have the same surface area could have the same volumes. Meanshile, other students consider that the rectangular prism formed by pasting the sides with the the length of 16 has the greater volume since it looks 'higher' and those with the length of 12 has the greater volume since it looks 'fatter'. This indicate that they only consider the visual image which no any supporting mathematical reasoning. However, some students tried using calculation by determining the area of base, which is in the form of regular quadrilateral, and then multiplied it by the height of the prism.

\section{Activity 11: Sing a song related to the volume of cuboids and cubes to strengthen students' retention of the volume of cuboids and cubes}

At the end of the lesson, students along with the teacher's guidance sing a song with the title "Cubes and Cuboids" to engage musical intelligence. This song is a song called "Kun Anta" which is known to most of the fifth graders, by changing the song lyrics according to the cube and cuboid material.

\author{
Kubus dan Balok \\ Hari ini belajar bangun ruang \\ Kubus dan balok.....delapan titik sudutnya \\ 6 sisi, 12 rusuknya \\ Tapi tak sama....kubus dan balok \\ Reff. \\ Rusuk x rusuk x 6...permukaan kubus \\ Rusuk pangkat 3...itulah volumenya \\ Oh Oh...persegi sisinya
}

\section{Translation:}

Cube and Cuboid

Today learn to build space Cubes and Cuboid ... the eight corners, the six sides, 12 edges. But it's not the same .... cubes and cuboid

Chorus.

Edge $x$ edge $x$ six ... surface area of cube Edge length to the power three ... that's the volume $\mathrm{Oh} \mathrm{Oh} . .$. the side square 
Oh Oh..sebelas jaring-jaringnya

Panjang . Lebar

Lebar . Tinggi

Tinggi . Panjang

permukaan balok

Carilah volumenya

Oh Oh.. panjang kali lebar kali tinggi
Oh oh...eleven nets of cube

Length, Width,

Width, Height,

Height, Length

cuboid surface area

Look for the volume

Oh oh..length times width times height

\section{DISCUSSION}

\section{Retrospective Analysis}

The HLT presented in Table 1 were used as a reference guide in answering research questions. HLT is compared with what happens in learning to investigate and explain how students can generalize the informal strategies from finding surface area and volume to the formal strategy. In addition, HLT was also compared with the data obtained to describe the development of strategies used by students and students' thought processes in understanding the concepts of surface areas and volume of cuboid and cube.

With regard to the RME learning, the situation in activities 1 to 11 has described all the RME characteristics that are expected to occur during learning, namely student's contribution which involves the influence of students to find their own volume concepts and the volume cuboid formula and interactivity shown by the establishment of communication. between students in groups and communication between students and teachers during group discussions and presentations. Meanwhile, intertwining occurs when students use the concept of rectangular area and the concept of multiplication when formulating how to find the volume of cuboid and cube, while the characteristics of the use of models in this learning are shown when students use rice and unit cubes as media for students to moving from the context of the rectangular prism problem in everyday life towards formal mathematics, namely the concept of volume of cuboid and cube. Hence, the use of context was also applied within the mathematical tasks as exemplified when finding the number of rice boxes.

Regarding how RME facilitate students' multiple intelligences, the learning design has accommodated activities which use words, pictures, gestures, rhythmic phrases, and the individual and collective experience as suggested by Bellanca (2008) and Karamikabir (2012). For example, when students carried out rolling activity when finding nets of cube, they were activating their kinesthetic intelligences to help them visualize the nets. For those who have more dominant visual/spatial intelligence, the activity of drawing structure of milo cubes from front, top, and right side views will help them to find the strategy of finding volume. In addition, for those who have dominant interpersonal intelligences, the student group experiences in 
almost all activities in our design will facilitate them express their emotion in every mathematical activity. For those who have dominant musical intelligences, the song would help them retain the concepts of volume and surface area of cuboid through the lyrics and the rhythmics.

The learning design was confirmed to follow cognitive process as suggested to find volume and surface area of cuboid and cube. The cognitive process proposed by Battista (2004) such as spatial structuring process where students abstract an object's composition and form by identifying, interrelating, and organizing its components was done, for instance, by the activity of finding the number of milo cubes needed to fill a box with a known size. In this activity, to spatially structure a rectangular array of cube units, the students saw it as the number of a rectangular shape which contain a number of milo cubes in which the number of rectangular shape indicates the layers or the height of the cuboid and the number of milo cube in each shape indicates the area of the rectangular shape. Beside spatial structure, understanding capacity is also vital to understanding volume (Hong \& Runnalls, 2020). In this learning design, it was accommodated by the early activities such as comparing two models of cuboid with sand and predict which box that contain more clay. When learning volume in activity of rearranging milo cubes into different rectangular model with different number of layers, students were found to have different solution methods. Some students used volume formula which is by multiplying the depth, the width and the height of the cuboid, whereas other used systematic counting, layer counting, or column/row iteration as reported by Tekin-Sitrava and Isiksal-Bostan (2018).

The learning design, however, meet some constraints such as unpreparedness of anticipating students who get missing with some prior knowledge required to solve any mathematical tasks within the activities in this learning design. This is indicated by students' inability to respond some mathematical tasks such as finding the number of milo cubes for a given image structure from top, side, and front views. Even though the students had started with the activity of drawing the top, side, and front views for some of the milo cubes structures given before carrying out the prediction activity, they still had difficulty determining the number of milo cubes precisely. Thus, it needs some smaller activities interconnecting those two spatial visualization activities. This challenged the future research to study how to design small activities among the main activities on the completed learning trajectory to support the local instructional theory produced in a design research agenda. 


\section{CONCLUSION}

To conclude, this design research produce a learning trajectory which facilitates students' multiple intelligence by transforming mathematical activities designed using RME learning approach into activities which are accordance with the characteristics of each intelligence such as verbal, logical/mathematical, visual/spatial, kinesthetic, and inter/intrapersonal intelligence. The learning trajectory are varied from the activities which lead students provide informal mathematics to the formal mathematics regarding the learning of volume and surface area of cuboid/cube. The sequence of activities includes rolling activity for cube/cuboid nets, making sense with volume and surface area, finding surface area through the net cube nets and cuboids, using rectangular models of paper of various sizes to be used as models for the cube/cuboid nets, and then determined the total area which represent surface area of cuboid/cube, building miniature buildings using cube unit model, predicting the number cube units in a box, constructing various models of cuboids to various sizes using particular number of cube units, rearranging a number of cube units arrangements with different layers to get different volume and surface area, and comparing the volumes of two rectangular prism made from the same rectangular model of paper.

\section{REFERENCES}

Adams, T. L. (2000). Helping children learn mathematics through multiple intelligences and standards for school mathematics. Childhood Education, 77(2), 86-94. https://doi.org/10.1080/00094056.2001.10521636

Armstrong, T. (2009). Multiple intelligences in the classroom. Ascd.

Bakker, A. (2004). Design Research in Statistics Education on Symbolizing and Computer Tools. Amersfoort: Wilco Press. https://dspace.library.uu.nl/handle/1874/893

Battista, M. T. (2004). Applying cognition-based assessment to elementary school students' development of understanding of area and volume measurement. Mathematical Thinking and Learning, 6(2), 185-204. https://doi.org/10.1207/s15327833mt10602_6

Bednar, J., Coughlin, J., Evans, E., \& Sievers, T. (2002). Improving Student Motivation and Achievement in Mathematics through Teaching to the Multiple Intelligences. Chicago: School of Education, St Xavier University. https://files.eric.ed.gov/fulltext/ED466408.pdf

Bellanca, J. (2008). 200+ Active Learning Strategies and Projects for Engaging Students Multiple Intelligences. Corwin Press.

Bustang, B., Zulkardi, Z., Darmawijoyo, H., Dolk, M., \& van Eerde, D. (2013). Developing a Local Instruction Theory for Learning the Concept of Angle through Visual Field Activities and Spatial Representations. International Education Studies, 6(8), 58-70. https://doi.org/10.5539/ies.v6n8p58 
Curry, M., Mitchelmore, M., \& Outhred, L. (2006, July). dyke In Proceedings 30th Conference of the International Group for the Psychology of Mathematics Education (Vol. 2, pp. 377384).

Fatoni, F., Putri, R. I. I., \& Hartono, Y. (2015). Permainan Tradisional Batok Kelapa dalam Membangun Konsep Pengukuran Panjang Kelas II SD. Jurnal Cakrawala Pendidikan, 1(1).

Gardner, H. (1999). Intelligence reframed: Multiple intelligences for the 21 st century. Basic books.

Gouws, E., \& Dicker, A. M. (2011). Teaching mathematics that addresses learners' multiple intelligences. Africa Education Review, 8(3), 568-587.

Gravemeijer, K. (2004). Local instruction theories as means of support for teachers in reform mathematics education. Mathematical thinking and learning,6(2), 105-128. https://doi.org/10.1207/s15327833mt10602_3

Gravemeijer, K., \& Cobb, P. (2006). Design research from a learning design perspective. Educational design research, 17-51.

Gravemeijer, K., \& van Eerde, D. (2009). Design research as a means for building a knowledge base for teachers and teaching in mathematics education. The Elementary School Journal, 109(5), 510-524. https://www.journals.uchicago.edu/doi/abs/10.1086/596999

Hasmiwati \& Widjajanti, D. B. (2020, July). Mathematics learning based on multiple intelligences with scientific approaches: How are their roles in improving mathematical literacy skills?. In Journal of Physics: Conference Series (Vol. 1581, No. 1, p. 012040). IOP Publishing.

Hasnidar, H., Sulihin, S., \& Elihami, E. (2020). Developing of multiple intelligences in students with the two stay two strays type. Edumaspul: Jurnal Pendidikan,4(2), 7-12. https://ummaspul.e-journal.id/maspuljr/article/view/680

Hong, D. S., \& Runnalls, C. (2020). Understanding length $\times$ width $\times$ height with modified tasks. International Journal of Mathematical Education in Science and Technology, 51(4), 614-625. https://doi.org/10.1080/0020739X.2019.1583383

Işık, D., \& Tarım, K. (2009). The effects of the cooperative learning method supported by multiple intelligence theory on Turkish elementary students' mathematics achievement. Asia Pacific Education Review, 10(4), 465. https://doi.org/10.1007/s12564009-9049-5

Karamikabir, N. (2012). Gardner's multiple intelligence and mathematics education. ProcediaSocial and Behavioral Sciences, 31, 778-781. https://doi.org/10.1016/j.sbspro.2011.12.140 
Kohar, A.W \& Rosyidi, A.H. (2013) The Development of Mathematics Learning Instruments Integrating Multiple Intelligences on Topics of Cuboid and Cube For The Eighth Grade Students of Junior High School. In: Zulkardi(Eds).The First South East Asia Design/ Development Research (SEA-DR) International Conference, April 22nd-23rd, 2013, Unsri, Palembang. https://repository.unsri.ac.id/9707/1/P3_Ahmad_Kohar_31.pdf

Murni, S., \& Ruqoyyah, S. (2020). Development of Teaching Materials Using A Realistic Mathematics Education Approach In A Multiple Intelligences Perspective of Elementary School Students. PrimaryEdu-Journal of Primary Education, 4(2), 208-219. http://www.e-journal.stkipsiliwangi.ac.id/index.php/primaryedu/article/view/1912

Taylor, A. R., \& Jones, M. G. (2013). Students' and teachers' application of surface area to volume relationships. Research in Science Education,43(1), 395-411. https://doi.org/10.1007/s11165-011-9277-7

Temur, O. D. (2007). The Effects of Teaching Activities Prepared According to the Multiple Intelligence Theory on Mathematics Achievements and Permanence of Information Learned by 4th Grade Students. International Journal of Environmental and Science Education, 2(4), 86-91. https://files.eric.ed.gov/fulltext/EJ901272.pdf

Tezer, M., Ozturk, R., \& Ozturk, C. (2015). A Case Study on the Effect of Geometry Course in High Schools by Multiple Intelligence Theory. Procedia-Social and Behavioral Sciences, 197, 31-37. https://doi.org/10.1016/j.sbspro.2015.07.044

Revina, S., \& van Galen, F. (2011). Spatial Visualization Tasks to Support Students' Spatial Structuring in Learning Volume Measurement. Indonesian Mathematical Society Journal on Mathematics Education, 2(2), 127-146. http://dx.doi.org/10.22342/jme.2.2.745.127$\underline{146}$

Sack, J. J. (2013). Development of a top-view numeric coding teaching-learning trajectory within an elementary grades 3-D visualization design research project. The Journal of Mathematical Behavior, 32(2), 183-196. https://doi.org/10.1016/j.jmathb.2013.02.006

Salmah, U., \& Putri, R. I. I. (2015). Ten-Structure as Strategy of Addition 1-20 by Involving Spatial Structuring Ability for First Grade Students. International Education Studies, 8(11), 16. https://doi.org/10.5539/ies.v8n11p16

Sulaiman, T., Abdurahman, A. R., \& Rahim, S. S. A. (2010). Teaching strategies based on multiple intelligences theory among science and mathematics secondary school teachers. $\begin{array}{llll}\text { Procedia-Social and Behavioral Sciences, } & 8,\end{array}$ https://doi.org/10.1016/j.sbspro.2010.12.070

Susilo, T. A. B., Reza, M. D., Fachrudin, A. D., Widadah, S., \& Kohar, A. W. (2018). Pembelajaran Matematika Realistik yang Melibatkan Kecerdasan Majemuk Pada Materi Volume Bangun dan Luas Permukaan untuk Sekolah Dasar. Jurnal Edukasi, 4(2), 99-122.

Tekin-Sitrava, R., \& Isiksal-Bostan, M. (2018). The Nature of Middle School Mathematics Teachers' Pedagogical Content Knowledge: The Case of The Volume of Prisms. Australian Mathematics Teacher, 74(1), 22-30. 
Van den Heuvel-Panhuizen, M., \& Buys, K. (2008). Young children learn measurement and geometry: A learning-teaching trajectory with intermediate attainment targets for the lower grades in primary school. Brill Sense.

Wijaya, A. (2008). Indonesian Traditional Games as Means to Support Second Graders' Learning of Linear Measurement. Mathematics Educations Master Thesis. Utrecht University.

Wijaya, A. (2012). Pendidikan matematika realistik suatu alternatif pendekatan pembelajaran matematika. Yogyakarta: Graha Ilmu. 